\title{
Algumas dificuldades no ensino de filosofia para crianças
}

\author{
Ígor Vinhal Nepomuceno_(1)
}

Resumo : O texto parte de algumas experiências do Projeto Filosofia na Escola para levantar algumas questões que dizem respeito aos limites e alcances do trabalho de filosofia com as crianças, fazendo também uma reflexão sobre o sentido aberto pelo ensino de filosofia para pensar as práticas pedagógicas nas quais a filosofia está envolvida.

Os últimos meses do projeto Filosofia na Escola, em 2004, foram essenciais para repensar todo o projeto, assim como a nossa conduta em sala de aula perante os alunos. A Semana de Extensão da Universidade de Brasília (evento que acontece sempre no segundo semestre de cada ano, incluindo seminários, mesas-redondas, palestras e oficinas das mais variadas áreas; assim como uma série de eventos culturais e artísticos, como teatro, música, dança) serviu como gancho para dar início a uma série de discussões sobre o que estamos fazendo dentro desse projeto. Assuntos como ideologia, emancipação, o direito de fazer o que fazemos e até como fazemos, foram temas que me vieram à cabeça com uma certa freqüência desde então.

Antes disso, porém, penso que o que primeiro iniciou esse processo de repensar todo o projeto e nossa postura diante dele foi uma inversão feita durante as próprias oficinas. Em certo momento, resolveu-se que inverteríamos os papéis: os alunos das séries iniciais da Escola Classe 06 de Planaltina seriam professores e nós seríamos seus alunos. Os alunos (que atuariam na oficina como professores) tiveram a liberdade de planejar a oficina inteira, desde a seleção dos temas até a organização das aulas. O que se pretendia com isso é que eles evidenciassem, nessa troca de funções, o que eles pensam que é filosofia e como eles acham que uma aula de filosofia deve ser. Assim, nós teríamos a possibilidade de avaliar não só as nossas aulas até então, mas também o que eles pensam do que fazemos nas oficinas que oferecemos a eles. Ou seja, teríamos a possibilidade de perceber o que eles pensam da nossa aula, visto que isso se manifestaria através da oficina que eles nos oferecessem.

Nesse dia, durante a discussão após a oficina, pudemos perceber claramente que eles puderam vivenciar muitas das dificuldades pelas quais os próprios professores passam. Eles sentiram a necessidade de uma organização: cada um deve levantar o dedo antes de falar, não por motivo de ordem e repressão, mas para que assim todos possam escutar o que o outro está falando; sentiram também que a falta de respeito $e$ a falta de participação por parte dos alunos pode ser muito frustrante $e$ às vezes até impedir o andamento da aula. 
Esses sentimentos (e outros mais), ao meu ver, foram importantes para que eles mesmos pensassem sobre suas próprias posturas em sala de aula.

Entretanto, não acho que tenha sido esse o maior retorno dessa atividade. A forma como eles coordenaram a oficina é que foi de fundamental importância. No geral, todos percebemos que a oficina consistia basicamente em elaborar perguntas.

Parece que a única coisa que se precisa fazer para filosofar é levantar uma série de perguntas que nos tiram da posição confortável da certeza, nos levam a uma pequena dúvida, a qual não se desenvolve e tudo fica por isso mesmo. Pois outra pergunta já é feita e a discussão se perde. Isso foi o que aconteceu na minha oficina e, pela discussão posterior (com todos os mediadores), me parece que foi o que aconteceu também na maioria das outras oficinas.

Esse evento levantou várias perguntas na minha cabeça. Por que eu fiquei um pouco frustrado com esse resultado? De onde veio essa frustração?

Uma frustração só pode vir de uma expectativa criada anteriormente. Porém, criar uma expectativa, pode ser criar também uma finalidade. E não é isso que se pretende no âmbito desse projeto. Criar uma finalidade é também determinar aonde se quer chegar. $\mathrm{O}$ que muitas vezes limita também como chegar $e$ as condições para se chegar. Com isso, o ideal de filosofia como experiência do pensar - uma investigação conjunta (professor e aluno), uma construção comum de conhecimento em lugar de uma simples transferência - pode ir por água abaixo.

Se por um lado queremos praticar filosofia com as crianças sem, no entanto, estabelecer uma finalidade para isso e sem esperar que isso nos leve a algum lugar (pois isso já seria um fim), por outro lado, nos frustramos com a avaliação que fazemos dos resultados a que chegamos.

Disso decorrem outras perguntas: como caminhar sem estabelecer a forma correta para isso e sem demarcar o caminho, mas mesmo assim chegar a algum lugar? E como avaliar e julgar o lugar em que chegamos? Ou seja, como dar aulas de filosofia sem querer chegar a algum lugar, mas também sem se frustrar com o lugar a que se chegou? Uma vez que não estabelecemos uma finalidade, um fim, não devemos nos frustrar com o estágio (2) a que chegamos.

Se por um lado a filosofia não deve ter uma finalidade pré-fixada, por outro isso pode levá-la a não chegar simplesmente a lugar nenhum. Como encontrar um equilíbrio entre esses dois extremos (3) é a minha inquietação.

Acredito que a filosofia pode ser útil na formação do indivíduo, visto que trabalha com a reflexão, com o pensamento, com a crítica, a autocrítica, a reflexão; com o ouvir, o falar, o pensar e o escrever. Porém, sei que a filosofia não é a única capaz de fazer isso. E sei também que isso não pode ser o que vai guiar a minha ação, pois assim eu estabeleceria uma finalidade para a filosofia, e com isso limitaria toda minha ação e de meus alunos. 
O que eu espero dos alunos quando entro em sala para fazer uma oficina, ou melhor, o que eu espero que aconteça durante uma oficina, em resumo, é um debate. Uma discussão. Um diálogo, uma troca mútua (e até mesmo uma reconstrução) de idéias, pensamentos e posições. Eu entro em sala com o intuito de conversar e discutir, mas entro também propício à minha própria mudança. Mas o que me dá direito a ter essa expectativa? Ela pode me auxiliar nesse processo? Atrapalhar-me? E ainda: o que me dá o direito de achar que eu posso dar uma aula de filosofia para alguém?

Essas questões (a finalidade/resultado das aulas de filosofia, a minha posição em sala, o meu direito de ser professor) me levam a questões ainda mais amplas. Será que se pode dar aula de filosofia? Como lecionar filosofia com hora marcada? Existe uma hora para começar a pensar e uma hora para parar de pensar? E será, mesmo que conseguíssemos chegar a uma educação libertadora, uma educação emancipadora, que conduzisse os alunos a uma reflexão autônoma $e$ completamente própria, será que o mundo em que vivemos permitiria isso? Será que seria favorável, para o sistema em que vivemos, crianças que pensassem criticamente sobre consumismo, direitos, leis, deveres, liberdade, as instituições e etc? O que seria feito por parte do próprio sistema para impedir que isso acontecesse?

Todas essas perguntas andam me inquietando bastante. E têm-me feito repensar toda a noção de educação que eu tinha até então.

Hoje em dia eu penso não só sobre as aulas e as melhores didáticas para se lecionar essa ou aquela aula. Não penso somente se o sistema aceitaria ou não uma educação libertadora. Mas penso também no próprio direito que me é dado de lecionar algo para alguém.

Com isso sinto minhas bases, que antes eram firmes e certas, agora como oscilantes e duvidosas. Eu me sinto questionando todas as certezas que antes eu tinha. É claro que isso pode parecer algo negativo, visto que minha ação já não é mais tão certeira como eu acreditava que ela fosse. Porém, só o fato de eu estar levantando tantas questões em minha mente, de estar pensando e relativizando tanta coisa, isso já é algo positivo. A própria investigação é positiva. Mesmo que eu chegue ao mesmo lugar em que antes eu me encontrava. Ou mesmo que eu não chegue a lugar algum e tenha que conviver para sempre com essas incertezas.

Para tentar aliviar essas tensões iniciei a leitura de um livro de Paulo Freire e Ira Shor, "Medo e Ousadia". Este é um livro que me parece muito promissor.

Conforme estou lendo-o, estou começando a perceber que muitas de minhas inquietações são também parecidas com as que os dois levantam naquele livro. É um livro bastante interessante não só porque trata de assuntos que dizem respeito à prática do professor, do seu dia-a-dia, mas principalmente pela forma como ele foi escrito. Ele é um diálogo transcrito entre dois educadores discutindo questões diversas, as quais se assemelham enormemente com as questões que eu levantei aqui. 
Com esse livro eu não espero resolver todas as minhas inquietações, mas pretendo pelo menos organizá-las. Resolvê-las talvez seja impossível, mas uma simples compreensão mais profunda da problemática já pode ser bastante esclarecedora. Como ele é um livro que foi escrito com a intenção de discutir questões práticas do professor em sala de aula, eu penso que ele poderá me auxiliar bastante nesse processo.

\section{Referência}

FREIRE, Paulo \& SHOR, Ira. Medo e Ousadia. São Paulo: Paz e Terra, 2003.

(1) Estudante do Curso de Filosofia da UnB, bolsista do Projeto Filosofia na Escola; E-mail: igorvn@yahoo.com.br

(2) Uso aqui esse termo em oposição a 'fim'. No sentido de que aonde quer que se chegue com a filosofia (ou mesmo qualquer outra disciplina) esse lugar não é fixo. Sempre há a possibilidade de se recriar a problemática e 'migrar' para outro lugar.

(3) De um lado uma pré-fixação de objetivos, logo, uma pré-determinação também de metodologias, de formas de condutas e etc; de outro uma aula sem objetivo nenhum, sem razão alguma e que não nos leve a nenhuma reflexão a nenhum questionamento. 